\title{
Strateginen yhteistyö maitotiloilla
}

\author{
Erkki Laitila $^{1)}$, Margit Närvä ${ }^{1)}$, Matti Ryhänen ${ }^{1)}$, Timo Sipiläinen ${ }^{2)}$ ja Jyrki Rajakorpi ${ }^{1)}$ \\ ${ }^{1)}$ Seinäjoen ammattikorkeakoulu, SeAMK Elintarvike ja maatalous, Ilmajoentie 525, 60800 Ilmajoki, \\ etunimi.sukunimi@seamk.fi
}

${ }^{2)}$ Helsingin yliopisto, taloustieteen laitos, PL 27, 00014 Helsingin yliopisto, timo.sipilainen@ helsinki.fi

\section{TIIVISTELMÄ}

Maitotilan johtamisessa strategisen ajattelun ja suunnittelun merkitys kasvaa. Maitotilojen harjoittamasta strategisesta yhteistyöstä voi tulla merkittävä kilpailutekijä. Tutkimuksessa tarkastellaan maidontuottajien strategisen päätöksenteon näkökulmasta yhteistyön ja verkostoitumisen tuomien mahdollisuuksien hyödyntämistä, yhteistyön organisointia, tavoitteita ja kriittisiä menestystekijöitä sekä mahdollisuuksia vastata toimintaympäristön muutoksiin.

Tutkimus toteutettiin laadullisena tutkimuksena. Tutkimusaineisto koottiin haastattelemalla maidontuottajia ja heidän yhteistyökumppaneitaan. Haastateltaviksi valittiin yrittäjiä, joilla oli kokemusta toimivista ja/tai epäonnistuneista yhteistyösuhteista. Aineisto koostuu 45 teemahaastattelusta. Laadullis-induktiivista analyysia hyödyntäen tehtiin yleistyksiä ja tulkintaa aineistosta esiin nousevien näkökulmien perusteella.

Tulosten mukaan yhteistyötä ja verkostomaista toimintatapaa tukeva strateginen ajattelu on usein syntynyt pitkän ajan kuluessa. Positiiviset kokemukset yhdestä yhteistyösuhteesta ovat kannustaneet laajentamaan yhteistyötä uusiin toimintoihin ja aloittamaan yhteistyötä uusien kumppaneiden kanssa. Osa tutkimukseen osallistuneista maitotiloista toimii osana laajaa ja moniulotteista yhteistyöverkostoa. Yksittäinen yhteistyösuhde on usein operatiivinen, mutta yhteistyösuhteet yhdessä muodostavat strategisen kokonaisuuden, jota ilman maidontuottaja ei pysty saavuttamaan liiketoimintansa tavoitteita. Päätökset pohjautuvat strategiseen ajatteluun, mutta formaalinen strateginen suunnittelu ja kannattavuustavoitteen asettaminen on harvinaista. Maidontuottajien omien tavoitteiden yhteensopivuus suhteessa yhteistyön odotettuihin hyötyihin on määräytynyt pitkälti osallistujien yhtenevän strategisen ajattelun pohjalta.

Verkostoituminen on tuonut uusia mahdollisuuksia yritystoiminnan kehittämiseen. Yhteistyöllä haetaan kilpailuetua. Tulosten mukaan säästöjä saadaan erityisesti työ- ja pääomakustannuksissa. Tuottavuutta voidaan parantaa hyödyntämällä kumppaneiden yhteistä osaamista ja hankkimalla uutta teknologiaa.

Tärkeää on, että kaikki osallistujat kokevat hyötyvänsä yhteistyöstä. Onnistuneessa yhteistyössä osallistujien tavoitteet saadaan sovitettua yhteen kokonaisuuden kanssa. Osallistujilta edellytetään valmiutta muuttaa omia toimintatapoja. Yhteistyökumppaneiden on luotettava toisiinsa ja heidän on oltava luottamuksen arvoisia. Arvot, asenteet, tavoitteet, osaaminen ja henkilökohtaiset ominaisuudet vaikuttavat yhteistyön onnistumiseen. Laajojen yhteistyöverkostojen johtaminen edellyttää suunnitelmallisuutta ja liikkeenjohtotaitoa.

Yhteistyösuhteiden monipuolistuessa ja vastuiden kasvaessa tarvitaan sopimusmalleja ja kirjallisia ohjeita yhteistyösopimusten laadinnan pohjaksi. Tutkimustulosten perusteella laadittiin käsikirja, joka sisältää keskeiset näkökulmat yhteistyösuhteen suunnittelussa ja kehittämisessä.

Asiasanat: maidontuotanto, strategia, yhteistyö, verkostoituminen, kilpailukyky 


\section{Johdanto}

Kuluttajakäyttäytymisen muuttuminen, markkinaohjautuvuuden kasvu, maitotuotteiden vientikilpailun kiristyminen ja tuontipaineiden kasvu haastavat maitoketjussa toimia yrityksiä. Menestyäkseen kovenevassa kilpailussa maidontuottajien on tarkasteltava kriittisesti nykyistä toimintaansa ja haettava uusia vaihtoehtoja ja keinoja kilpailussa pärjätäkseen. Maidontuottajan on pystyttävä luomaan menestysstrategia, toteutettava se ja uusittava sitä muuttuvien vaatimusten myötä. Tämä edellyttää strategisen ajattelutavan omaksumista ja järjestelmällistä strategista suunnittelua.

Maidontuottajien harjoittamasta strategisesta yhteistyöstä voi tulla merkittävä kilpailutekijä. Tutkimuksessa tarkastellaan maidontuottajien strategisen päätöksenteon näkökulmasta yhteistyön ja verkostoitumisen tuomien mahdollisuuksien hyödyntämistä muuttuvassa toimintaympäristössä. Tutkimuksessa vastataan seuraaviin tutkimuskysymyksiin

- Miten maidontuottajat ovat hyödyntäneet yhteistyön ja verkostoitumisen tuomia mahdollisuuksia?

- Millaisia tavoitteita maidontuottajat ovat asettaneet yhteistyölle ja verkostoitumiselle?

- Miten maidontuottajat ovat organisoineet yhteistyötä?

- Mitkä ovat kriittisiä menestystekijöitä yhteistyön ja verkostoitumisen onnistumisessa?

Yhteistyön aloittaminen on strateginen päätös. Strategian laadinta on kokonaisvaltaista ja laaja-alaista yritystoiminnan pääsuuntalinjojen määrittämistä pitkälle tulevaisuuteen. Strategian luontia varten yritystoiminta on tarpeen jakaa eri osa-alueisiin eli segmentoida (Kamensky 2010). Segmentointi helpottaa määritettäessä, missä liiketoiminnoissa yhteistyötä ja verkostomaista yrittämistä kannattaa tehdä. Maitotilalla liiketoiminnot voidaan jakaa osa-alueisiin esimerkiksi seuraavasti: maidontuotanto, säilörehuntuotanto, rehuviljantuotanto ja hiehojen kasvatus. Tarvittaessa jakoa voidaan jatkaa yksityiskohtaistamalla sitä. Jako liiketoimintoihin voidaan tehdä useasta eri näkökulmasta, kuten mm. prosessi- ja teknologiavalinnat, kumppanit ja heidän tarpeensa, kilpailijat, muut sidosryhmät sekä osaaminen ja kilpailutilanne. Jokaiselle liiketoiminnolle muodostetaan oma kilpailustrategia. Maidontuotannossa se on yleensä kustannusjohtajuus.

Strategiatyössä panostetaan keskeisiin menestystekijöihin. Strategisten tavoitteiden painopiste on toimissa, joilla haetaan kilpailuetua eli parannetaan maitotilan kilpailuasemaa. Strategisten tavoitteiden on tuettava pitkällä aikavälillä taloudellisten tavoitteiden kuten kannattavuuden, maksuvalmiuden ja vakavaraisuuden saavuttamista. Jos yhteistyöllä ei saavuteta taloudellisia tavoitteita, hankkeesta kannattaa luopua.

Maidontuottajat voivat tehdä yhteistyötä toisten maidontuottajien, muiden maatalousyrittäjien ja urakoitsijoiden kanssa. Yhteistyön ja verkoston rakentamisen tavoitteena on taloudellinen hyöty verkoston toimintaan osallistuville. Kaikkien yhteistyöhön osallistuvien on koettava hyötyvänsä siitä. Kuviossa 1 on esitetty yhteistyöverkoston rakentamisessa tarvittavia näkökulmia. Yhteistyöverkostoa rakennettaessa on huomioitava sekä jokaisen osallistujan näkökulma että yhteistyösuhteen näkökulma.

Osanottajien näkökulmasta tarkasteltuna keskeistä on muodostaa suunnitteilla olevalle yhteistyölle yhteinen strategia, arvioida kunkin osanottajan näkökulmasta strategisesta yhteistyöstä odotettavissa olevat hyödyt ja haitat, yhteistyössä tarvittavat resurssit sekä yhteistyön vaikutuksia kunkin osanottajan toimintaprosesseihin. Jokaisen potentiaalisen osanottajan on itsenäisesti arvioitava, ovatko yhteistyön tuomat hyödyt suuremmat kuin sen mahdollisesti aiheuttamat haitat. Hyötyjen ja haittojen arvioimiseksi on yhteistyösuhteesta oltava riittävästi tietoa.

Yhteistyösuhteen näkökulmasta tarkasteltuna oleellista on päättää yhteistyön sisällöstä ja organisoitumisesta. Suunnitteilla olevaa yhteistyöverkostoa tarkastellaan horisontaalisessa ja vertikaalisessa ulottuvuudessa, pohditaan yhteistyön syvyyttä ja yhteistyön organisointia. Yhteistyösuhteen organisoinnin taustalla ovat strategiset tavoitteet ja strateginen suunnitelma, jotka viedään käytäntöön päätöksentekomallin avulla. Sosiaalinen rakentuminen eli miten kumppanit valitaan ja miten luottamus ja yhteisymmärrys syntyvät ovat oleellisia taustatekijöitä. 


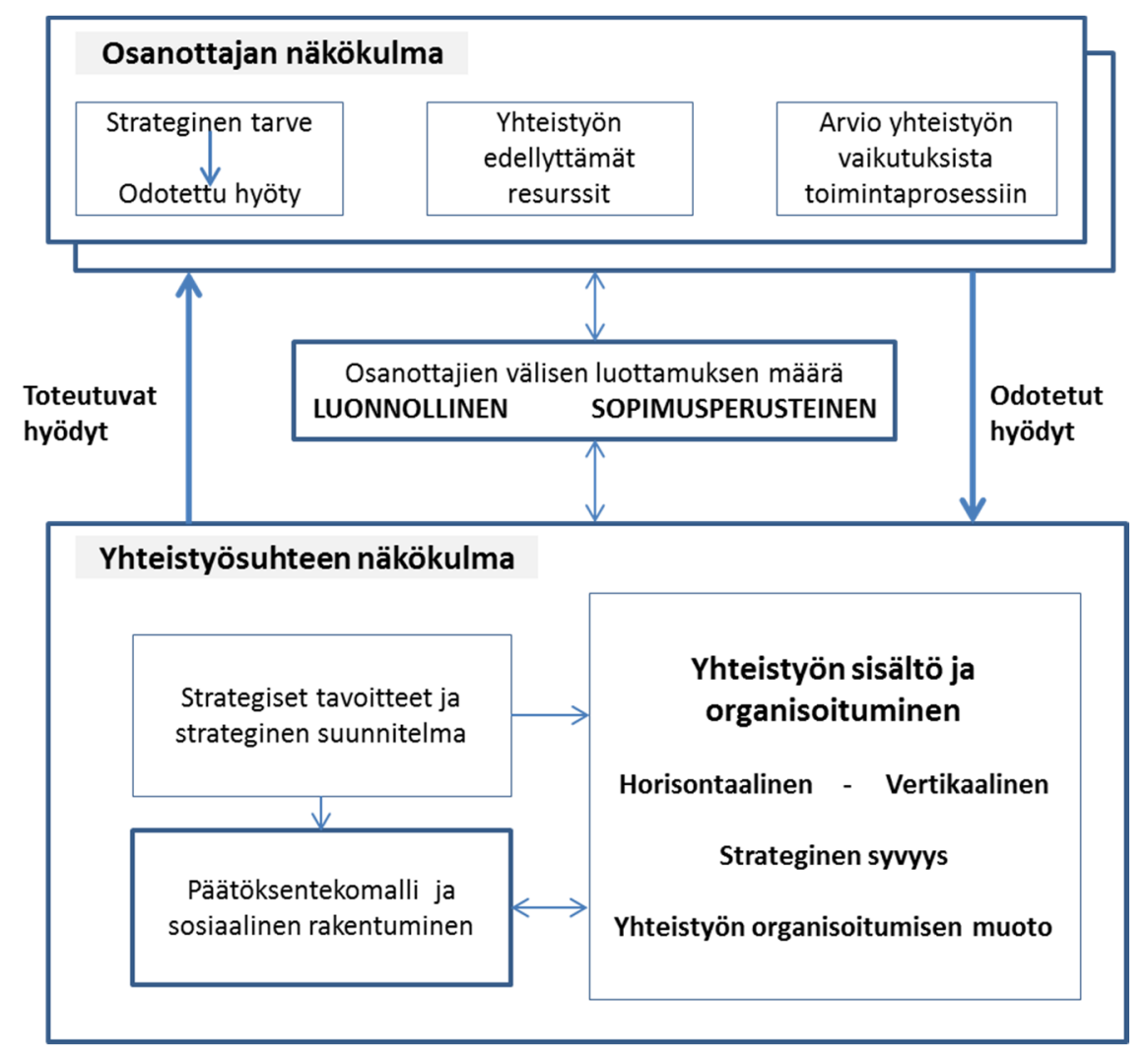

Kuvio 1. Yhteistyöverkoston rakentamisen analyysin viitekehys (Laitila ym. 2014a, 46).

Yhteistyöverkoston rakentaminen on monimuotoinen prosessi, johon on varattava riittävästi aikaa. Tiedon hankinta, suunnittelun eri osa-alueet ja suunnittelun eteneminen yhteistyöverkoston rakentamisen yhteydessä tapahtuu iterointiprosessina, jossa tiedon lisääntyessä ja suunnitellun edetessä eri vaiheisiin palataan uudestaan, eli prosessi etenee iteroiden osa-alueesta toiseen sekä eteen- että taaksepäin.

Yhteistyön rakentuminen lähtee liikkeelle yhteistyön ideoinnista. Sen jälkeen potentiaaliset osallistujat selvittävät omasta näkökulmastaan ideoidun yhteistyön hyödyt ja haitat sekä arvioivat yhteistyökumppaneiden soveltuvuutta yhteistyöhön. Vesalaisen $(2002,50)$ mukaan sosiaalisissa sidoksissa tärkeää on luottamus, tiivis vuorovaikutus, tiedonvaihto, oppiminen ja yhteinen ajattelutapa. Mikäli potentiaalinen osanottaja arvioi, että yhteistyön hyödyt ovat sen mahdollisia haittoja suuremmat, hänen kannattaa olla mukana yhteistyön tarkemmassa suunnittelussa. Yhteistyöasetelma suunnitellaan niin, että yhteenlaskettu hyöty maksimoituu. Yhteistyösuunnitelman perusteella potentiaaliset osanottajat arvioivat oletetut hyödyt ja haitat sekä tekevät lopullisen päätöksen mukaan lähtemisestä tai pois jäämisestä. Yhteistyöhön mukaan lähtevät tekevät suunnitelman, jossa tarkennetaan yhteistyön strategiset ja operatiiviset tavoitteet ja päätetään, miten toiminta organisoidaan ja johdetaan.

\section{Aineisto ja menetelmät}

Tutkimus toteutettiin laadullisena tutkimuksena. Hirsjärven, Remeksen ja Sajavaaran $(2009,161)$ mukaan kvalitatiivisen tutkimuksen lähtökohtana on kuvata elämää, jossa todellisuus on moninainen. Tässä tutkimuksessa tutkimusmenetelmäksi valittiin laadullinen tutkimus, koska tutkimuksessa tuotettiin uutta tietoa maitotilojen yhteistyöasetelmista, jotka kuvattiin mahdollisimman todentuntuisesti ja useita eri näkökulmia huomioiden.

Maitotilojen yhteistyöasetelmista kerättiin tietoa teemahaastatteluin. Haastateltaviksi valittiin maidontuottajia, maidontuottajien kanssa yhteistyötä tekeviä muita maatalousyrittäjiä sekä urakoitsijoita. Haastateltavat olivat valinneet yhteistyön ja/tai verkostoitumisen osaksi yrityksensä strategiaa.

Tutkimusaineisto sisältää 45 teemahaastattelua. Haastattelut tehtiin joulukuun 2013 ja helmikuun 2014 välisenä aikana. Hirsjärven ym. $(2009,164)$ mukaan yksi laadullisen tutkimuksen tunnusmerkeistä on aineiston monitahoinen ja yksityiskohtainen tarkastelu. Tässä tutkimuksessa analysoitiin maitotilojen 
yhteistyöasetelmia kirjallisuuden perusteella rakennetun viitekehyksen avulla, joka on esitetty kuviossa 1. Haastattelut litteroitiin ja ne analysoitiin laadullis-induktiivisesti viitekehystä vasten.

\section{Tulokset}

\section{Yhteistyön ja verkostoitumisen tuomien mahdollisuuksien hyödyntäminen}

Yhteistyöhön ryhtyvät yleensä sellaiset maidontuottajat, joiden strateginen ajattelutapa tukee yhteistyötä. Tällainen yhteistyötä tukeva strateginen ajattelu on usein syntynyt vaiheittain pitkän ajan kuluessa. Yleensä yhteistyö on aloitettu yhdessä toiminnossa, esimerkiksi puinnissa. Kun tästä on saatu myönteisiä kokemuksia, on yhteistyötä laajennettu myös muihin toimintoihin ja osa-alueisiin, joko samojen tai uusien kumppaneiden kanssa. Jos taas ensimmäiset yhteistyökokemukset ovat olleet kielteisiä, päädytään useassa tapauksessa korostamaan strategisessa ajattelussa itse tekemistä.

Yhteistyön korostaminen toimintatapana pohjautuu yhteistyötä tukevaan strategiseen ajattelutapaan, mutta yksittäiseen yhteistyösuhteeseen lähteminen perustuu yleensä esiin tulleen mahdollisuuden hyödyntämiseen tai ilmaantuneen uhkan eliminointiin, jolloin strateginen ajattelutapa ohjaa etsimään ratkaisua yhteistyöstä. Esimerkiksi kylvöurakoitsijan lopettaminen on pakottanut etsimään uutta toimintatapaa, jolloin urakoitsijan asiakkaat ovatkin hankkineet yhteisen koneen. Formaalinen strateginen suunnittelu ja kannattavuustavoitteiden asettaminen on harvinaista.

Yhteistyön strategisen ajattelunsa lähtökohdaksi ottaneet maidontuottajat hyödyntävät yhteistyötä ja verkostoitumista usean eri operatiivisen yhteistyösuhteen avulla. Heillä on yleensä samanaikaisesti useita yhteistyökuvioita ja yhteistyökumppaneita. Kun tarkastellaan yksittäisiä yhteistyösuhteita, ovat ne yleensä operatiivisia. Kun tarkastellaan maidontuottajan yhteistyösuhteita kokonaisuutena, muodostuu niistä strateginen kokonaisuus, jossa maidontuottaja ei ilman yhteistyöverkostoa pysty saavuttamaan liiketoimintansa tavoitteita.

Yhteistyötä ja verkostoitumista hyödynnetään pääosin ydinliiketoiminnan ulkopuolisissa toiminnoissa. Maidontuottajat kokevat omissa käsissä pidettäväksi ydinliiketoiminnaksi maidon tuottamisen. Myös säilörehun tuottaminen koetaan ydinliiketoiminnaksi, vaikka sen piirissä tehdäänkin laajaa yhteistyötä. Yhteistyö kohdistuu pääosin kasvituotantoon ja valtaosa yhteistyöstä on koneyhteistyötä.

\section{Yhteistyön tavoitteet ja hyödyt}

Yhteistyöllä haetaan kilpailuetua. Haastatellut toivat esille yhteistyön strategisia tavoitteita, jotka olivat useimmiten pyrkimys alentaa yksikkökustannuksia ja keskittää resursseja ydinliiketoimintaan.

Keskeisinä syinä yhteistyöhön ryhtymiselle haastateltavat nimesivät (ei tärkeysjärjestyksessä) kokonaistyömäärän alentamisen ja työn keskittämisen ydinliiketoimintaan, työhuippujen vaatiman lisätyöpanoksen varmistamisen, sidotun pääoman määrän alentamisen ja uudelleen kohdentamisen, rahoituksen ja tukien saamisen, yksikkökustannusten alentamisen ja uuden teknologian hyödyntämisen.

Tavoitteena on ollut tuottavuuden parantaminen hyödyntämällä kumppaneiden yhteistä osaamista ja hankkimalla uutta teknologiaa. Onnistunut koneyhteistyö alentaa sidotun pääoman määrää ja nostaa koneiden käyttöastetta. Uusi teknologia parantaa työnjälkeä ja tuotelaatua. Yhteistyö tuo työnsäästöä sekä lisää kokonaisosaamista, mikä alentaa yksikkökustannusta ja mahdollistaa pääoman tehokkaan allokoinnin. Kustannussäästöjä syntyy myös välillisesti kuten laadukas säilörehun korjuuteknologia tuo säästöjä ruokinnassa.

Useat haastateltavat olivat hakeneet tai ainakin pohtineet yhteistyötä myös hiehonkasvatuksessa. Keskeisiä syitä ovat kokonaistyömäärän hallinta, parsipaikkojen lisääminen maidontuotantoon sekä rehualan riittävyys. Pisimmälle viety yhteistyöasetelma maidontuotannossa on yhteisnavetta. Syyt yhteisnavetan perustamiselle ovat samanlaisia kuin muissakin edellä kuvatuissa yhteistyöasetelmissa, erityisesti työmäärän hallinta, pääoman tehokas allokointi ja yksikkökustannusten alentaminen ${ }^{1}$.

\section{Yhteistyön organisointi}

Yhteistyön organisointi riippuu sen tavoitteista ja tarpeista. Yhteistyön muodot voidaan jakaa seuraavasti: tuotantopanosten hankintayhteistyö (yhteisostot), yhteisomistus, viljelijöiden keskinäinen vaihtotyö ja keskinäinen urakointi, ulkoistaminen (koneurakointi, hiehonkasvatus, jne.), yhteisyritystyyppiset ratkaisut (esimerkiksi yhtiöitetty koneasema) ja yhteisyksikkötyyppiset ratkaisut (esim. yhteisnavetta).

\footnotetext{
${ }^{1}$ vrt. Laitila ym. 2012, 118-125
} 
Hankintayhteistyöllä tavoitellaan kustannussäästöjä tuotantopanosten hankinnassa. Koska hankintayhteistyöstä saatava hyöty perustuu suuriin ostomääriin, edellyttää yhteistyön toimivuus osanottajien sitoutumista sovituksi määräajaksi siinäkin tilanteessa, että jollekin tarjottaisiin suurempia etuja itsenäisesti toimien. Sitoutuminen perustuu haastateltavien mukaan luottamukseen, tiukkoja sanktioituja sopimuksia ei yleensä tehdä.

Yhteisomistuksessa resurssi, tavallisesti kone, hankitaan yhdessä niin, että kukin rahoittaa oman osuutensa. Pyrkimyksenä on sidotun pääoman määrän vähentäminen, koneen käyttöasteen nostaminen ja mahdollisuus saada käyttöön tehokasta teknologiaa. Yhteisomistuksen ongelmana haastateltavat pitävät sitä, että toisen käytössä kone kuluu nopeammin tai rikkoutuu helpommin kuin toisen käytössä.

Keskinäisen vaihtotyön tavoitteet ovat samat kuin yhteisomistuksessakin. Toiminta vain on organisoitu niin, että kukin käyttää omaa konettaan. Useimmiten pyritään siihen, että työmäärät menevät tasan joko tunteina laskettuna tai ajankäyttö koneen arvolla painottaen. Rahaa ei liikuteta, vaan luottamukseen perustuen pyritään siihen, että työmäärät tasapainottuvat. Keskinäinen urakointi poikkeaa edellä esitetystä siten, että konetunneille on sovittu hinta ja esimerkiksi kerran vuodessa tasataan keskinäinen tili. Markkinahintaisella urakoinnilla tarkoitetaan jonkin toiminnon tai osaprosessin ulkoistamista, jolloin kysymys on normaalista yritysten välisestä kaupankäynnistä, jolloin hinta, toimitusvarmuus ja laatu ratkaisevat kaupan syntymisen ja yhteistyön jatkumisen.

Yhteisyksikkötyyppisiä ratkaisuja on rakennettu pääasiassa koneyhteistyötä varten (koneasemat ym.). Tavoitteena on koneiden käyttöasteen nostaminen ja yksikkökustannuksen alentaminen siten, että osakastilat muodostavat peruskuorman ja loput koneiden kapasiteetista pyritään myymään markkinaehtoisena urakointina. Yhtiömuotoisella organisoinnilla haetaan selkeyttä yhteistyön organisointiin. Yhteisyksiköt ovat maidontuotannossa yleensä yhteisnavettoja. Niiden tavoitteena on saavuttaa etua yksikkökustannusten alentamisessa suurtuotannon etujen avulla sekä hallita työmäärää ja riskejä.

\section{Yhteistyön kriittiset menestystekijät}

Menestyvän yhteistyön luonnollinen lähtökohta on, että kaikki osallistujat kokevat hyötyvänsä yhteistyöstä. Lähes kaikki haastateltavat korostivat osanottajien keskinäisen luottamuksen oleellista merkitystä. Maatalouden yhteistyösuhteissa, toisin kuin suuryritysten kohdalla, luottamus muodostuu henkilöiden välille, koska yritykset personoituvat yhteen tai enintään muutamaan henkilöön. Useat yhteistyösuhteet ovat laajentuneet vähitellen ja näin ollen keskinäinen luottamuskin on syventynyt ja tullut testatuksi ajan kuluessa ja sen vuoksi ei ole koettu tarpeelliseksi suunnitella yhteistyötä yksityiskohtaisesti. Haastateltavat kokivat, että kumppaneiden kanssa on opittu elämään eikä tarvetta yksityiskohtaisille sopimuksille ole. Uudet, usein yhtiömuotoiset yhteistyösuhteet on yleensä suunniteltu määrämuotoisesti. Niissäkin on usein "tuttu porukka" ja määrämuotoinen suunnittelu liittyy lähinnä rahoittajan tai tuenantajan vaatimukseen eikä ole lähtenyt osanottajien koetusta tarpeesta suunnitella strategiaa tai hanketta yksityiskohtaisesti.

Useat haastateltavat painottivat, että on nähtävä yhteistyön nettohyöty, koska yhteistyöllä on aina myös haittapuolia johonkin toiseen toimintatapaan verrattuna. Hyödyn saaminen yhteistyöstä edellyttää osallistujien joustamista omasta parhaaksi koetusta toimintatavasta niin, että yhteenlaskettu hyöty maksimoituu. Joustavuus merkitsee erilaisten luonteiden hyväksymistä ja sietämistä sekä joustoa töiden toteutuksessa. Käänteisesti voidaankin todeta, että keskeisenä yhteistyön esteenä haastateltavat pitivät joustamattomuutta. Mikäli joku kumppaneista jäykästi pitää kiinni totutusta toimintatavasta, ei yhteistyö todennäköisesti toimi. Jotkut haastateltavat näkivätkin yhteistyön lisäämisen hankalana, koska se edellyttää totuttujen toimintatapojen muuttamista.

Haastatteluissa nousi esiin, että joustavuuden mahdollistaa suunnitelmallisuus. Verkostoitunut toimintamalli edellyttää, että kukin osanottaja suunnittelee oman toimintansa niin, että kaikkien etu tulee huomioon otetuksi. Luonnollisesti myös yhteistyöasetelma on organisoitava suunnitelmallisesti, että kukin osanottaja voi sen pohjalta suunnitella oman työnsä kaikkia hyödyttävällä tavalla.

Haastateltavat nostivat tärkeäksi yhteistyön edellytykseksi myös kaikkien osanottajien riittävän vahvan taloudellisen aseman. Jokaisen osanottajan on kyettävä suoriutumaan yhteistyöhön liittyvistä maksusitoumuksistaan. Implisiittisesti vastaajat toivat esiin, että yhteistyöhön ryhtyminen ei ole keino selviytyä omista, jo akuuteiksi päässeistä taloudellisista vaikeuksista. Yhteistyön edellytyksenä olevaa keskinäistä luottamusta ei voi syntyä, jos muut kokevat, että joku osanottajista käyttää muita hyväkseen.

Mahdollisuus onnistuneeseen yhteistyösuhteeseen syntyy, kun kaikki osanottajat kokevat edellä kuvattujen osatekijöiden olevan samanaikaisesti voimassa. 


\section{Johtopäätökset}

Maidontuottajan on seurattava toimintaympäristössä tapahtuvia muutoksia ja mietittävä keinoja ja toimintatapoja vastata muuttuvaan kilpailutilanteeseen. Yksi keino toiminnan kehittämiseen on yhteistyö ja verkostoituminen. Yhteistyön edellytyksenä on maidontuottajan verkostoitumista ja yhteistyötä tukeva strateginen ajattelu. Yhteistyön mahdollisuuksia on hyödynnetty useimmiten ydinliiketoiminnan ulkopuolisiin toimintoihin, erityisesti peltoviljelyyn. Yhteistyön strategisen ajattelunsa lähtökohdaksi valinneet maidontuottajat ryhtyivät yhteistyösuhteeseen tilanteen ilmaantuessa tai uhkan eliminoimiseksi. Määrämuotoinen, järjestelmällinen strateginen suunnittelu oli harvinaista. Vihtosen (2007) mukaan maatalousyrityksissä strateginen johtaminen on harvoin muodollinen tai säädelty toiminto.

Kaikissa tapauksissa menestyvä yhteistyö edellyttää osapuolilta riittävää joustamista, suunnitelmallisuutta, suurpiirteisyyttä ja sen lisäksi riittävää liikkeenjohtotaitoa ja toisten kunnioittamista. Yhteistyön edellytysten osalta tässä tutkimuksessa saadut tulokset ovat samansuuntaisia muissa liiketaloustieteellisissä analyyseissa saatujen tulosten kanssa, joissa yhteistyön edellytyksiksi nousevat osanottajien yhteneväinen arvomaailma, kumppanien arvostaminen, vastavuoroisuus, luottamus, vuorovaikutuksen avoimuus ja oman suoritustason ylläpitäminen (esim. Saarelainen 2013, 70-74, Blomqvist 2007, 178-190, Järvinen 2009).

Maitotilojen lukumäärän vähentyessä ja yrityskoon kasvaessa mahdollisuus vähitellen syntyviin, luonnollisiin yhteistyösuhteisiin vähenee, jolloin yhteistyötä on synnytettävä myös heidän kesken, jotka eivät riittävästi tunne toisiaan. Tällöin tietoinen strateginen suunnittelu, markkinaehtoinen ulkoistaminen, yhtiömuotoiset ratkaisut ja yksityiskohtainen etukäteen sopiminen voivat ainakin osittain korvata luonnollisen, vähitellen syntyvän keskinäisen luottamuksen.

Maidontuottajien verkostoituminen ja yhteistyösuhteet ovat syntyneet vaiheittain pitkän ajan kuluessa. Tulosten perusteella laadittiin yhteistyösuhteen suunnitteluprosessin nopeuttamiseksi ja täsmentämiseksi käsikirja (Laitila ym. 2014b), josta löytyy keskeiset näkökulmat yhteistyösuhteiden suunnitteluun ja kehittämiseen.

\section{Kirjallisuus}

Blomqvist, K. 2007. Kasvuyrityksen kilpailukyky - ei pelkkää teknologiaa. Teoksessa: M. Laukkanen (toim.) Kasvuyritys. Helsinki: Talentum. 178-190.

Järvinen, P. 2009. Menestyvän työyhteisön pelisäännöt. Helsinki: WSOYpro.

Kamensky, M. 2010. Strateginen johtaminen - menestyksen timantti. Talentum.

Hirsjärvi, S., Remes, P. \& Sajavaara, P. 2009. Tutki ja kirjoita. 15. uudistettu painos Helsinki: Tammi.

Laitila, E., Ryhänen, M., Närvä, M, Sipiläinen. T., Heiskari, M., Jokiaho, S., Ketola, J., Kämäräinen, S., Känsäkoski, H., Palo. A. \& Pieviläinen, A. 2012. Verkostomainen yrittäminen. Teoksessa: M. Ryhänen \& E. Laitila (toim.) Yhteistyö ja resurssit maitotiloilla. Verkostomaisen yrittämisen lähtökohtia ja edellytyksiä. Seinäjoen ammattikorkeakoulu. Seinäjoen ammattikorkeakoulun julkaisusarja B. Raportteja ja selvityksiä 59: 91-134.

Laitila, E., Ryhänen, M., Närvä, M., Sipiläinen. T. \& Rajakorpi, J. 2014a. Yhteistyö ja verkostomainen toimintatapa maidontuotannossa. Teoksessa: M. Ryhänen \& E. Laitila (toim.) Yhteistyö- ja verkostosuhteet. Strateginen tarkastelu maidontuotantoon sovellettuna Seinäjoen ammattikorkeakoulu. Seinäjoen ammattikorkeakoulun julkaisusarja A. Tutkimuksia 19: 18-78.

Laitila, E., Ryhänen, M., Rajakorpi, J., Närvä, M. \& Sipiläinen. T. \& 2014b. Yhteistyön käynnistämisen käsikirja. Teoksessa: M. Ryhänen \& E. Laitila (toim.) Yhteistyö- ja verkostosuhteet. Strateginen tarkastelu maidontuotantoon sovellettuna Seinäjoen ammattikorkeakoulu. Seinäjoen ammattikorkeakoulun julkaisusarja A. Tutkimuksia 19: 116-181.

Saarelainen, E. 2013. Kohti menestyvää liiketoimintamallia. Helsinki: Suomen Liikekirjat. Saarijärven Offset. Vesalainen, J. 2002. Kaupankäynnistä kumppanuuteen: Yritystenvälisten suhteiden elementit, analysointi ja kehittäminen. Tampere: Metalliteollisuuden kustannus Oy.

Vihtonen, T. 2007. Suomalaisten maatalousyritysten strategiset valinnat ja taloudellinen menestyminen. Helsinki: MTT. Maa- ja elintarviketalous -sarja 101. 